\title{
1 \\ Stress, strain and stability in the French party system
}

Alistair Cole

\author{
Introduction
}

Political parties do not find a natural breeding ground in France. Portrayals of French political culture point to incivisme, individualism and a distrust of organisations (Crozier, 1970, Pitts, 1981, Gaffney and Kolinsky, 1991). Though these representations are overly impressionistic, a powerful strand of French republicanism has denigrated political parties as divisive, fractious organisations. This is best exemplified by the Gaullist tradition, within which the political movement facilitates a direct relationship between the providential leader and the nation, but does not presume to intervene in this privileged relationship. The distrust of parties is deeply embedded in the ideology of the republican state itself, where the state represents the general will, superior to the particularistic interests represented by parties, groups and regions. There is no natural sympathy for doctrines such as pluralism which emphasise the importance of the corps intermédiaires between the citizen and the state.

At the same time, French political parties perform such essential functions as political mobilisation, the aggregation of interests, organising political competition, feedback, public management and political recruitment. Our aim in this chapter is to give an overview of the evolution of the French party system in the first forty-five years of the Fifth Republic, to examine the principal changes since the 1980s and to identify the underlying continuities in the party system.

The structure and evolution of the French party system

The history of French parties prior to 1940 was one of fragmentation and regional specialisation. A complex mosaic of political factions existed during the Third Republic. On the centre and right of the political 
spectrum, party labels either did not exist, or signified distinct political realities in different parts of the country. More centralised, coherent and disciplined parties gradually began to emerge after 1945 - in the form of the Christian democratic Mouvement Républicain Populaire (MRP) and de Gaulle's ephemeral Rassemblement du Peuple Français (RPF) but such parties were undermined by their internal divisions and by the corrosive effects of the Fourth Republican political environment. The situation was clearer on the left: since the Tours split in 1920, there had existed two well-organised rival parties, the Section Française de l'Internationale Ouvrière (SFIO) (PS from 1969) and the PCF. Historically speaking, these fraternal enemies of the left have experienced a relationship based on mutual distrust: long periods of internecine conflict and rivalry have been punctuated by much shorter episodes of left unity (the tripartite government of 1944-47, the 'Union of the Left' of 1972-77, the Mauroy government from 1981 to 1984 and the plural-left government from 1997 to 2002).

During the Third and Fourth Republics, the fragmented structure of the party system, along with the parliamentary basis of political power, had a direct and divisive impact upon governmental stability: no single party or coalition of parties could normally gather a lasting majority of support either within the country, or within Parliament to sustain majoritarian governments. Cabinets lasted an average of twelve months in the Third Republic, and seven months in the Fourth (Williams, 1964). This pattern changed abruptly with the creation of the Fifth Republic. After an initial period of confusion from 1958 to 1962 linked to the consolidation of de Gaulle's leadership, the party system became simplified between the 1960s and early 1980s on account of the bipolarisation process, streamlining parties into two rival coalitions of the left and the right. Beginning in earnest in 1962, the height of bipolarisation occurred in the 1978 parliamentary election. The structure of the party system in 1978 was that of a bipolar quadrille. Four parties of roughly equal political strength together obtained over 90 per cent of the vote and divided voter preferences evenly between the PCF and the PS in the left coalition, and the neo-Gaullist RPR and the liberal conservative UDF on the right.

There are several explanations for this process of rationalisation. The first relates to the institutional rules of the game. From this perspective, the enhanced prestige of the presidency as modelled by de Gaulle between 1958 and 1969, the bipolarising pressures of the direct election of the president after 1962 - only two candidates go through to the decisive second ballot - and the strengthening of executive government in the constitution of the Fifth Republic all operated in favour of a rationalised party system. The institutional argument emphasises the emergence of the presidency as the linchpin of the political system from 1958 to 1986 (Wright, 1989). Consequently, the key contenders for office gradually 
refocused their attentions upon the presidential election: to exercise influence, parties had to form part of rival presidential coalitions. The existence of disciplined, pro-presidential coalitions controlling the $\mathrm{Na}$ tional Assembly for most of the period since 1958 was in stark contrast to the Fourth Republic, where governments were short-lived and multifarious, usually based on unstable coalitions and shifting party alliances. Until 1986, parliamentary majorities were elected to support the President. At the time of writing in the summer of 2002, the argument remains pertinent that the institutional architecture of the Fifth Republic and rules of the game favour a bipolarised party system, as we shall see later on when we briefly consider the 2002 elections. In historical terms, these institutional factors were even more important. With the emergence of strong, stable governments encouraged by the 1958 constitution, parties were deprived of their former capacity for Byzantine political manoeuvre in an Assembly-dominated regime.

A separate but related institutional argument highlights the role of the two-ballot electoral system in parliamentary elections (Bartolini, 1984). By its discriminatory effects against smaller parties, the two-ballot system forced the centre parties to choose between the Gaullist-led majority and the left in order to survive. The two-ballot system also provided powerful incentives for ideologically neighbouring parties, such as the PCF and PS, to form alliances, and it stalled minor parties, such as the Greens or the FN, at important stages of their development. While the discriminating effects of the majoritarian system are obvious, the electoral system has not in itself prevented the emergence of new parties. Electoral systems can operate in variable manners according to underlying political circumstances. While the two-ballot system has penalised centre parties for most of the Fifth Republic, it strengthened centre parties in the Third Republic (Goldey, in Bogdanor and Butler, 1982). One must also therefore bear in mind specifically political factors, most notably: the political leadership of de Gaulle; the historic impact of Gaullism and its role as a federating force of the centre and right; the survival instinct of the left-wing parties; the rejuvenation of the French PS and the rebalancing of the French left in the 1970s; the talented mobilisation of prejudice by Jean-Marie Le Pen during the 1980s and 1990s.

Finally, analysis of party system evolution must also incorporate a third series of explanations based on social change: these vary from neo-Marxist arguments relating to the emergence of the social class as the salient electoral cleavage, giving a sociological underpinning to left-right bipolarisation, to sociological analysis pinpointing the emergence of the "new middle classes' as the central groups in post-war French society, favouring the emergence of broad-based parties such as the PS (Bacot, 1976, Mendras, 1989).

Since the mid-1980s, however, the structure of the French party system 
has become far less neatly balanced, giving way to a more complex pattern of uncertain and changing contours. There has been an increase in the number and a change in the nature of parties and the issues processed through the political system. The bipolar contours of the French party system have been challenged by the emergence of new political issues, such as immigration, security and the environment, and the difficulties experienced by the mainstream parties in articulating these new political demands. When observing the French party system in 2002, one is struck by the increasingly manifest opposition between a formal, bipolar and structured party system as represented in national political institutions (especially the National Assembly and municipal government) and an underlying multipolar, fragmented and contestataire pattern of party support.

The three main developments in the past two decades have been: the emergence of a series of minor but significant parties, and in particular the breakthrough, persistence and subsequent division of the $\mathrm{FN}$; the changing dynamics of factional and coalition politics, perhaps most clearly demonstrated in the decline of the PCF and the emergence of the PS as the dominant party of the left; and patterns of growing electoral instability, namely increased electoral volatility (each election since 1978 going against the incumbent government) and a certain disaffection towards traditional politics, as demonstrated in higher abstention rates and the weakening of the parties of the 1978 bipolar quadrille. Overall, while the PCF, PS, UDF and RPR obtained over 90 per cent of the vote in 1978, in 1997 and 2002 these parties obtained around 67 per cent. While there are many enduring features of party system stability, which we will explore in the final section, we are primarily concerned in the subsequent section to identify stresses and strains and to map out the important changes that occurred in the 1980s and 1990s.

\section{Stresses and strains in the French party system}

\section{The challenge of new parties}

The emergence of new parties (or the breakthrough of previously marginal parties) and the reaction of pre-existing players to these party newcomers is the most obvious development. The most significant of these parties are the Greens and Lutte Ouvrière (LO) on the left, and the FN on the right (Cole, 1998). There has been a plethora of more temporary and marginal forces that have had a lesser, but real, impact upon specific elections, or across particular issues. Such ephemeral or marginal forces as La Droite of Charles Millon, the RPF of Charles Pasqua and Philippe de Villiers, the Mouvement Ecologiste Indépendant (MEI) of Antoine Waechter, and Saint-Josse's Chasse Pêche Nature Traditions (CPNT) fit 
this category. These movements testify to the importance of 'flexible specialisation' (Kitschelt, 1997) as issue-specific parties rise and fall to exploit the contradictions of broader-based structures. These marginal parties invariably define themselves as being against the parties of the political establishment and perform better in 'second-order' elections fought under proportional representation (regional elections, European elections) than in the decisive parliamentary or presidential elections. In the 2002 National Assembly election, a total of 8,455 candidates presented themselves in 577 constituencies, an average of 14.65 per seat, the highest ever. ${ }^{1}$

By far the most significant of these parties is the FN. With around 15 per cent in the 1995 presidential, 1997 parliamentary and 1998 regional elections, the FN could already claim to be the second formation of the French right. In the first round of the 2002 presidential election, Le Pen and Mégret, the two candidates of the far right, polled almost 20 per cent between them (16.86 per cent for Le Pen, 2.34 per cent for Mégret) outpolling the combined Socialist-Communist total in mainland France.

In party system terms, the success of the $\mathrm{FN}$ above all harmed the mainstream right, or, at least, it did until 2002. For almost two decades, the FN damaged the cohesion of the parties of the right by posing highly divisive dilemmas of alliance strategy, organisational discipline, political philosophy and policy adaptation. The tripartite structure of the French right (RPR-UDF-FN) has been its undoing ever since the breakthrough of the FN in 1982-83. We can illustrate the corrosive effects of the far right by comparing the 1997 and the 2002 National Assembly elections. In 1997, consistent with Le Pen's desire to defeat the Juppé government by fair means or foul, the FN maintained its candidates wherever it could on the second ballot. There were 76 left-right-FN triangular contests; the left won 47, the right 29. Given the closeness of the result, the FN's tactics undoubtedly facilitated the arrival in power of the Jospin government. In the changed political circumstances of the 2002 National Assembly elections, the far-right parties were less able to influence the outcome of the mainly bipolar left-right second-round contests (Cole, 2002). With a reduced first-ballot score in 2002 (11.33 per cent for the FN, 1.10 per cent for the MNR), the FN was less able to provoke the three-way contests that had been particularly damaging for the parties of the mainstream right in 1997. In 2002 there were only 9 three-way fights, down from 76 in 1997. There were 28 duels between the FN and UMP (from 56 in 1997) and only 8 duels between the left and the FN (from 25 in 1997). The right won back 43 of the seats it had lost as a result of three-way contests in 1997 (Jaffré, 2002). The main difference between the two elections related to the level of FN support, as well as the degree of unity of the mainstream right parties (low in 1997, high in 2002), a theme to which we shall return. 
The real impact of the $\mathrm{FN}$ lay in its agenda-setting role. At its height, the $\mathrm{FN}$ forced issues such as immigration and security onto the political agenda and ensured that they remained there. If primarily detrimental to the mainstream right in party system terms, the FN had a corrosive impact on all existing parties, especially insofar as it skilfully exploited the theme of the political corruption of the pro-system parties, the RPR, UDF and PS.

\section{From faction to party}

One of the most striking developments of the 1980s and 1990s was the rise of internal factionalism in almost all major political formations. There is nothing new about party factionalism. Divisions within parties were inherent in the parliamentary organisation of the Third and Fourth Republics. In the Fifth Republic, the modern PS was reconstructed after 1971 as an explicitly factional party, with the right to free expression of factions (courants) guaranteed within the party's constitution. Initially the preserve of the PS, in the 1990s party factionalism became as characteristic of the RPR and UDF, not to say the PCF and FN.

The most intractable factional conflicts arise in relation to personal rivalries, political strategy and policy differences. Personal rivalries testify in part to the normal contradictions of human agency. They also respond to precise institutional incentives in the Fifth Republic, to the pivotal role of the presidential election and, recently, to the organisational incentives for ambitious politicians to stand as a candidate for the presidency. ${ }^{2}$ Even more than personal rivalries, however, during the 1990s the main parties, and especially the RPR and UDF, were divided on the question of alliance strategy and in relation to specific policy issues such as Europe and immigration. Though there has been a narrowing of distinctive economic policy positions between the main parties, issues such as European integration and immigration have divided existing parties and cut across traditional lines of political cleavage. The neo-Gaullist RPR was divided over European integration; the UDF was split wide open by the question of immigration and alliances with the FN.

It is sometimes difficult to distinguish between personal rivalries, questions of political strategy and policy differences. During the late 1990 s and into the new century, the existence of a myriad of structures fronted by innumerable second-rank party leaders - Madelin's DL, Bayrou's UDF, Pasqua's RPF, de Villiers' MPF, Chevènement's Mouvement des Citoyens (MdC), Baylet's PRG and so on - increased the impression of permanent, personality-based competition, even though each political formation occupied a distinctive position along the political spectrum and was engaged in a relationship with one or more of the main political families. 
If the first twenty years of the Fifth Republic were characterised by a tendency for the emergence of broad-based coalitions, the last decade of the twentieth century sorely tested the capacity for rassemblement of the main political formations. Each of the main party families experienced a schism within its midst, as there was a general move from faction to party. This move occurred within the PS (the creation by Jean-Pierre Chevènement of the MdC), the RPR (the creation of the RPF by Pasqua) the UDF (the breakaway of Alain Madelin and DL) and even the FN (the split of December 1998 and the creation of Mégret's MNR). Paradoxically, the pitiful performance of all of these factions-cum-parties has reinforced the centrality of party and of the main political families. While factions can often exercise influence within a party, once outside of the party fold their influence is either negative and short-lived (as in the case of Chevènement in the 2002 presidential election) or non-existent. As the case of DL and Madelin's deal with the UMP demonstrates, ambitious politicians need to operate within one of the main party organisations.

The diminishing legitimacy of party politics?

Various converging forces allow us to pose the diminishing legitimacy of party politics as a central research question. However we interpret the success of the FN - as a modern variant of Fascism or as something else - the persistence at a high level of support for two decades of a populist far-right party reveals an ambivalent attitude towards existing political supply, and indirectly towards liberal democracy, among a significant minority of voters. The inadequacy of political supply can be measured in other ways, most notably by the diminishing support for representatives of the two main political families, PS and RPR, and by growing rates of abstention. In the 1994 European election, the two leading lists were reduced to a combined total of 40 per cent; in 1999, this figure was even lower. On the first round of the 1995 presidential election, the two leading candidates (Jospin and Chirac) polled just over 40 per cent of the vote, a far weaker proportion than in any other presidential election (Cole, 1995). In 2002, the two leading candidates (Chirac and Le Pen) did even worse: with 36.74 per cent of voters and barely over a quarter of those registered to vote (Cole, 2002)

France's historic political families were each challenged on the first round of the 2002 presidential election, at which Jean-Marie Le Pen won through to the second-ballot run-off against Jacques Chirac. Communists, Socialists, Gaullists, Liberals, Christian Democrats, even Greens performed under par. None of these candidates did as well as they might have expected and many voters were dissatisfied with all of them. The strong performance of the far-left and far-right candidates, the high abstention rate (at 28.30 per cent, a record in any presidential election) 
and the general dispersion of votes to candidates not generally considered to be genuine presidential contenders such as St Josse, Chevènement and others were all part of this trend. Chirac and Jospin, the prematurely 'preordained' second-round contenders, obtained only just over one-third of votes and one-quarter of registered voters between them.

The corollary of this is the development of parties and movements which have defined themselves against the existing political elites, such as the FN, but also LO and the Ligue Communiste Révolutionnaire (LCR). While these forces are marginal in the bipolar party system, they demonstrate the survival of a tradition of radical politics on the far left and extreme right, potently recalled on the first-round of the 2002 presidential election when the far left (10.44 per cent) and extreme right (19.20 per cent) captured almost one-third of votes between them. The persistence and strengthening of the parties of the far left and especially of the extreme right articulates a profound disillusion towards the "parties of government' of all complexions on behalf of the popular (workingand lower-middle-class) electorate. More than ever, the Le Pen electorate in 2002 was over representative of those suffering from the most acute sentiments of economic and physical insecurity. Le Pen was the favoured choice of the lower-middle classes (31.9 per cent) and of workers (26.1 per cent), far outdistancing both the Socialist Jospin and the Communist Hue in working-class support. ${ }^{3}$ The French electorate's vote on 21 April 2002 suggested an unresolved tension between French identity, the implicit promises of French citizenship (including the economic promises) and the uncertainty provoked by Europeanisation, globalisation and an unpredictable future.

A more general cause of fragility lies in the pessimism of public opinion, which has lacked faith in political parties, broadly defined, to resolve intractable policy problems. This has tormented each government since 1981. After the economic miracle of les trente glorieuses (1945-74), political parties in government have proved incapable of dealing with the perception of prolonged economic crisis. In comparative European perspective, the reality of the French crisis is debatable, but the perception of economic malaise has had a destabilising effect on all incumbent governments since 1974. The real yardstick against which governments have been measured - unemployment - has proved to be particularly intractable. Since 1981, every single decisive election (presidential or parliamentary) has gone against the incumbent government, in a manner that suggests the electorate's dissatisfaction with the performance of successive governments.

This lesson was repeated in 2002, when the Prime Minister of the outgoing plural-left government failed even to reach the second round of the presidential election. In a very real sense, the 2002 campaign was fought as a single-issue campaign, but this time over the issue of 
insecurity rather than unemployment. Events and campaign strategies converged to define the agenda. A concatenation of events - the MiddleEast crisis, the aftermath of 11 September, and above all a set of particularly shocking murders and violent disorders in France itself set the agenda for the two months of the 2002 campaign proper. In all other recent election campaigns, the theme of unemployment has emerged as the principal preoccupation of voters. Not so in $2002-$ SOFRES polls demonstrated that from January 2000 insecurity had replaced unemployment as the principal subject of concern of French voters (Gerstlé, 2002). To some extent, Jospin was a victim of his own success in bringing down unemployment rates. The unemployment problem was perceived as less acute than in the past, surpassed in importance by the ubiquitous theme of insecurity, much less favourable political terrain for a centre-left candidate.

Political variables are equally pertinent in explaining dissatisfaction with existing political supply. For over two decades, the problem of corruption has been at the top of the political agenda (Mény, 1992). There is some evidence of endemic political corruption, and much media speculation around the subject. Political corruption has centred on the operation of local and regional government, the imperatives of party finance and organisation, the attribution of public markets and personal enrichment. In the classic schema, political parties have received occult commissions for attributing public markets; any firm must factor the party commission into its bid. Cases of personal enrichment are rarer, but there are several celebrated examples to demonstrate the enduring appeal of avarice (Evans, 2002). The problem of corruption is a complex one. Most corruption cases have involved raising finance to fight prohibitively expensive election campaigns. While corruption has probably always existed, new incentives have been provided by the decentralisation laws, which leave important powers of planning and the attribution of public markets in the hands of mayors and their adjoints. More cases of corruption have been uncovered as a result of the increased activism of the juges d'instruction (investigating magistrates). The negative political fallout of any hint of corruption is such that incumbent ministers, such as Strauss-Kahn in November 1999, invariably resign if they are investigated by the juge d'instruction, even before any formal allegations have been made.

The French party system was shaken to its core by problems of political, institutional and ideological coherence throughout the 1980s and 1990s. Party fragility was real, but there were also countervailing forces in play. In the ensuing section, we identify three underlying causes of party continuity: institutional incentives, flexible and adaptable party organisations, and the absorptive capacity of the main French political traditions. 


\section{Underlying continuities in the French party system}

The prestige of the presidency, and the majoritarian effects of the two-ballot electoral system are potent institutional variables. In a formal sense, at least, the bipolar party system remains a structural variant of the rules of political competition in the Fifth Republic, though we observe an ever-increasing gap between formal bipolarity, on the one hand, and the underlying fragmentation of electoral choice on the other.

The electoral series of 2002 defied many basic bipolar rules of the Fifth Republic. The first round of the presidential election did not produce a run-off between left and right. The second round was a quasi-referendum for democracy that produced the largest victory for any candidate in any free election in recent memory. The changing role of the presidential election points to the danger of attributing eternal features to the operation of particular political institutions. Rather than supporting from the first round the candidate they ideally want to see elected president (as in the traditional slogan, 'Choose on the first round, eliminate on the second'), voters have begun treating the first round of the presidential election as a 'second-order' election, expressing a preference in the same way they would in a regional or European election. That the 2002 campaign was closed rather than open encouraged such a fragmentation of support. The belief that the first round did not count encouraged voters to support minor or extreme candidates, either through obstinacy or as a way of influencing the agenda of the candidate eventually elected President. There was certainly a lot of choice. With sixteen candidates in competition in 2002, the first round played the role of a non-decisive proportional election, with the bulk of voters firmly believing in a Chirac-Jospin run-off. That this outcome did not materialise deprived the second round of its usual left-right configuration.

On 9 and 16 June 2002, the French party system returned to something resembling its normal bipolar state. Two parties - the UMP on the right and the PS on the left - occupied almost 90 per cent of parliamentary seats, a far greater measure of bipartisanship than in recent elections. The hegemony of the UMP on the right was matched by a domination of the Socialists on the left, in votes as well as in seats. The far-left parties (2.83 per cent) were squeezed by the movement to use usefully for the Socialists, as was the PRep, ${ }^{4}$ with just over 1 per cent, and, to a lesser extent, the Greens ( 4.5 per cent) and the Communists ( 4.8 per cent). The far right lost one-third of its electorate by comparison to 21 April (11.33 per cent for the FN, 1.10 per cent for the MNR) and was unable to repeat its spoiling tactics of 1997, when it had helped the left win the election. In elections fought under the single-member constituency twoballot system, the four parties of the 1978 bipolar quadrille (PCF, PS, 
RPR and UDF) have continued to dominate parliamentary representation. Only one deputy (out of 577) was elected in 1997 from outside the rival electoral coalitions and none in 2002. Because the vast bulk of parliamentary seats are confined to members of the left or right electoral coalitions, the ability to form alliances is crucial. Its isolation has deprived the FN of major national parliamentary representation except in the 1986-88 legislature.

In addition to the institutional underpinnings of the Fifth Republic, the cohesion of the French party system also rests upon the bedrock of municipal office (as witnessed by the longevity of the generation of mayors first elected in 1977) which has itself been transformed into an arena of (mainly) bipolar political competition. The bipolar basis of political competition in the Fifth Republic has spilled over into local municipal and cantonal elections fought under the two-ballot system; since 1977, municipal elections in the large cities have by and large been contested by rival left and right lists, a pattern confirmed in 2001 .

Structural explanations, then, are important in identifying how the institutional rules of the game have shaped important aspects of party competition in the Fifth Republic. But they do not tell the whole story. They have difficulty in distinguishing between different types of party supply and they underplay the dynamic and unpredictable qualities of the party system, as demonstrated by the breakthrough of new parties and the adaptation of older ones.

The underlying stability of the French party system also rests upon flexible and adaptable party organisations. This is a double-edged sword. On the one hand, French citizens appear more reluctant to join party organisations than their northern European counterparts. Mass membership parties of the German or Scandinavian variety are rare; only the Gaullists and Communists have presented examples of mass parties and both are a shadow of their former selves. But this relative weakness of party organisation stricto sensu has certain advantages. The weakness of organic links with the trade unions or business, for example, has allowed French parties to reposition themselves more convincingly than their counterparts in certain other European countries. More generally, flexible organisational forms are well adapted to the particular structure of incentives in the French polity, focused on the exercise of power in municipal government as well as on the conquest of decisive (presidential and parliamentary) elections. Here we would again emphasise the importance of municipal government. For certain parties (PS, UDF), municipal government has served as a long-term substitute for a powerful party organisation; for others (PCF, RPR), municipal government has underpinned the illusion of a genuine party organisation. Once the municipal support is removed, the organisational chimera is laid bare. Even 'strong' parties, such as the PCF and RPR, rely more on the logistical 
infrastructure provided by municipal government than on their formal party organisations. This is demonstrated in numerous former Communist municipalities such as Le Havre where the PCF organisation has been severely damaged following the loss of the municipal council.

The weakness of party organisation is not necessarily synonymous with a lack of organisational efficiency. The renewal of the French Socialist Party in the 1970s was predicated upon an open dialogue with voluntary associations much more than upon a revival in party membership. Their cross-cutting membership served the interests both of the party and supportive voluntary associations, facilitating the exchange of policy ideas and personnel. In their own very different ways, the Greens and the FN learned a similar lesson in the 1990s. The organisational capacity of the French Greens has been strengthened by the strong links maintained with voluntary associations (not just environmental groups). In the case of the FN in Orange and Toulon, the far-right municipalities created a network of parallel associations under the tutelage of the town hall (McAna, 2001), somewhat along the lines of traditional Communist-run municipalities. These practices have positive and negative characteristics. They can be interpreted as embodying new forms of political participation. They can also contribute to a lack of transparent governance - municipally financed associations are sometimes little more than vehicles for the exercise of informal partisan influence.

Lastly, the robust character of the main political traditions principally underpins the stability of the French party system: French-style communism, socialism, liberal conservatism, Gaullism, Christian democracy and national populism. They can each trace their lineage back to the Second World War or much earlier, and have each demonstrated the capacity to reinvent themselves to cope with changing circumstances and political incentives. Even when threatened by the rise of new parties and by the manifestations of disaffection with existing political supply, over time the French party system has proved its absorptive capacity. The 'absorptive capacity' (Hanley, 1999a) of the French party system is particularly marked on the left. This is demonstrated by the ability of the PS to transcend internal divisions and changing ideological fashions, and retain its dominant position on the left. The emergence of the Greens as a post-materialist, new-politics party forces us to modify this appreciation, but only partially: the three Green deputies are entirely dependent on alliances with the PS.

It is rather more difficult to apply the thesis of the absorptive capacity of the party system to the French right. This has been hampered by its divisions ever since the decline of historic Gaullism and the creation of the RPR and UDF in the 1970s. In addition, the rise of the FN from 1983 onwards has posed acute dilemmas of alliance strategy and political positioning for the parties of the mainstream right. The FN was a problem 
because the right was divided, hence too weak to ignore the far-right movement. The failure of the RPR to stamp its authority on the French right during the 1990 s was all the more damaging in that a Gaullist President occupied the Elysée palace from 1995 onwards.

In one important respect, the 2002 electoral series represents a return to the sources of the Fifth Republic. Once re-elected President, Chirac imposed the creation of the UMP as a presidential platform to which all existing right-wing parties would have to subscribe. UMP candidates had to accept to sit in the same parliamentary group in the National Assembly, to support the President and to participate in the creation of a vast new party of the French right in autumn 2002. A committee containing representatives of the three main pro-Chirac parties (RPR, DL, part of the UDF) but heavily weighted in favour of the RPR distributed UMP candidacies in the parliamentary contest. François Bayrou led the resistance of a centrist rump, retaining the title UDF and pledging critical support for Jacques Chirac. The presidential party strategy worked exactly to plan. This strategy involved not just providing a majority for the President, but also engineering a realignment within the right in favour of the RPR, to sweeten the pill of the dissolution of the Gaullist movement into a much broader conservative party.

The 2002 elections represented the first time since 1973 that there had not been at least two major parties on the French right. Right-wing unity paid off handsomely. The UMP won an overall majority (399 seats out of 577), only the third time in the history of the Fifth Republic that a single political formation has held an overall majority. ${ }^{5}$ In 2002, the UMP formula masked a new domination of the RPR. With the election of an overall majority for a single formation of the mainstream right, the French party system again resembles in part that of the 1960s, whereby a dominant presidential rally is flanked by a small centre party, a 'reservist' force of the right whose existence is barely tolerated.

However, the capacity for absorption is limited to the formal party system, as measured in decisive elections fought under the second-ballot system. It can account neither for fragmentation of party support in second-order elections, or for the evidence of dissatisfaction with political supply and demand that we uncovered in the previous section. One explanation of party persistence might be that parties gives expression to deeply embedded cleavages. Joachim Schild (2000) summarises the principal cleavages in French politics as being positional (left versus right), existential (religious versus lay), ideological (cultural liberalism versus authoritarianism), socio-economic (class conflict) and issue-based. We have argued elsewhere that these variables lourdes have lessened in significance since the early 1980s (Cole, 1998). The left/right cleavage remains pertinent in certain respects, but its mobilising force has been diminished as a result of the Mitterrand presidency and the decline of 
the PCF. The religious-lay cleavage retains the capacity to mobilise opinion on specific issues such as the defence of, or opposition to écoles libres, but the relation of cause and effect is uncertain. We demonstrated above that ideological cleavages can cut across party lines, as can those based on issues. Voting patterns corresponded far less neatly to social class identities in 2002 than they did in 1978 (Cole, 2002, Capdevielle et al., 1981, Perrineau and Ysmal, 1998). The electoral volatility of the new middle classes and the strengthening of the FN among the workingand lower-middle-class electorate explain these cross-cutting pressures. Moreover, as the issue of European integration demonstrates, party structures do not always correspond neatly to divisions over issues or ideologies. Traditional cleavages have clearly lessened in importance, as France has undergone multiple internal and external changes, but they remain as cognitive maps within the collective memory. While there is no easy relationship between political attitudes and behaviour, partisan lenses can provide one way of comprehending and reinterpreting a changing environment.

\section{Conclusion}

The decline of parties is not terminal; it is contingent on underlying political and economic circumstances. We can draw three main conclusions from the partially contradictory evidence presented in this chapter. Party system change is the first one. That the French party system has undergone strains and stresses is obvious. The challenge of new parties, the decline of certain older parties (notably the PCF) and the limited capacity of existing parties to articulate new political issues have had an impact on the number and the nature of parties. The issues processed by the party system reflect a changing policy agenda. On the one hand, new political issues such as the environment and immigration have forced their way onto the agenda. On the other, governmental realism and the end of 'lyrical illusions' associated with the abandoning of a certain type of left project under Mitterrand have refocused elite attention on public policies, rather than competing visions of society. Partisan discourses have not proceeded apace. The resulting distance between political discourse and policy achievement has created disillusion and demobilisation among many French voters.

This is one of the most convincing explanations of the public disaffection with political parties during the 1980s and 1990s. This aspect of the crisis of party politics is more apparent in France than in comparable countries. Because partisan discourses are deeply embedded in French republican political culture, public expectations have been higher and the electoral retribution for failure has been harsher. This is the specifically French 
dimension of a broader pan-European phenomenon, whereby established party families have had to adapt to a series of internal and external shocks over the past two decades, cognisance of which has preconditioned their ability to survive and prosper.

Indeed, this absorptive capacity of the main political families modifies the first conclusion. While the traditional parties were at times unnerved by the new-issue politics, the resulting new parties such as the Greens and the FN failed to replace the existing players. The Greens owe their political survival to the PS. Over a long period, the FN has articulated a powerful strand within French public opinion and indirectly influenced the political agenda. Without allies, however, it has failed to translate its electoral potential into full political capital and has lacked second-round credibility, both in the 2002 presidential contest (where Le Pen polled 17.85 per cent against 82.15 per cent for Chirac) and in parliamentary elections, where the FN usually fails to hold on to its first-round vote in those rare constituencies where it can fight the second.

The existing parties absorbed the fluid centre of gravity of French politics. They occupied a strategically and organisationally privileged position to adapt to and interpret a changing internal and external political agenda. The same process transformed the leading parties, and especially the PS and RPR, in important respects both by the exercise of domestic power and by the changing European and international policy agenda.

We conclude thereby in the persistence of a rather artificial bipolar multipartism, the left and right coalitions functioning most effectively when one party assumes a dominant role - the Gaullists from 1962 to 1974, and the PS from 1981 onwards. This leads naturally to our third and final conclusion. To the extent that two blocs provide the mainstay of political competition across most European countries, French party competition has moved closer to the mainstream European model. As in most West European democracies, the mainstay of political competition is between left of centre and right of centre parties and their respective political allies. The pattern of party fragility in the 1980s and 1990s was not specific to France but in many respects formed part of a pan-European adjustment to the end of post-war prosperity. The form that such fragility took in France - the rise of the extreme right, increased abstention, a weakening of party identity - was nationally specific, but similar phenomena could be observed in comparable countries such as Italy (where the entire post-war party system collapsed under the weight of political corruption), Germany (where the 'new politics' prospered on the failure of traditional social democracy) and Britain (where the electoral swing of 1997 broke all post-war records).

To achieve a just measure of the balance between party stress and party stability, we can learn from longitudinal historical and cross-national 
comparison. Longitudinal comparison suggests that there is no real equivalent to the party system stress of the Fourth Republic in the late 1940s, when the PCF and RPF - forces openly antagonistic to the regime - obtained the support of half of the voters. We must not lose a sense of perspective. From a cross-national perspective, while allowing for nationally tinted referential frames and for the discursive traditions of the main political traditions, we observe that the pressures on the French party system are broadly consistent with those observed elsewhere.

\section{Notes}

1 The inflated number of candidates in 2002 was mainly attributable to the rules on campaign finance, which allow parties to obtain state funding on the condition that they field candidates in at least 50 constituencies.

2 Candidates obtaining the signatures of at least 500 elected officials (mainly rural mayors) are eligible to stand for the presidency and participate in the official campaign, which gives them free media coverage. Candidates with over 5 per cent of valid votes get their campaign expenses reimbursed, up to a limit of 7,460,000 euros.

3 Figures from the Louis Harris-Libération-AOL post-election poll published in Libération, 23 April 2002.

4 This was the name given to Chevènement's presidential rally. Pro-Chevènement candidates stood in over 400 constituencies in the parliamentary election, but fared poorly.

5 The Gaullists from 1968 to 1973 and the Socialists from 1981 to 1986 are the other examples. 